\title{
Doubling of Farmers' Income though Integrated Farming System Approaches in Bihar- A Review
}

\author{
Dayanidhi Chaubey $^{1 *}$, Ved Prakash ${ }^{1}$, Tikam Chand Yadav ${ }^{2}$ and Garima Singh ${ }^{1}$ \\ ${ }^{1}$ Department of Agronomy, Bihar Agricultural University, \\ Sabour (Bhagalpur) - 813 210, (Bihar), India \\ ${ }^{2}$ Department of Soil Science and Agricultural Chemistry, \\ Jawaharlal Nehru Krishi Vishwavidhyalya, Jabalpur (M.P.) - 482 004, India
}

*Corresponding author

\begin{tabular}{|l|}
\hline Ke y w o r d s \\
GAP, IFS, MSP \\
reform, Smart \\
Farming
\end{tabular}

\section{Keywords}

GAP, IFS, MSP

reform, Smart

ticle Info

Accepted:

Available Online:

ember 2018

\section{A B S T R A C T}

Under Indian context, the prosperity of a country depends upon the welfare of farmers and majority of the Indian farming communities follow traditional norms of agriculture which support their livelihood. Farming in India is characterized by small, marginal, and fragmented land holdings (about 86 per cent) and is highly depended on monsoon showers. Operating small holdings is often unviable and in this situation, farming is not a profitable business or enterprise. In the context of Bihar, major challenges and issues in agriculture are the occurrence of flood, drought and hail storm as well as high cost and meager availability of quality seeds, fertilizers, irrigation, lack of marketing facility, low storage, and processing facilities etc. Therefore, there is an urgent need of transformation in agriculture production combined with integrated farming system (IFS) approaches that involves crop cultivation, dairy, poultry, fishery, mushroom cultivation, agro-forestry, piggery, beekeeping, vegetable and fruit production, use of renewable energy source (i.e. Solar energy, Biogas) etc. For doubling of the farmer's income few vital strategies need to be adopted considering the basic requirements of the farmers. These strategies might be massive investments in agricultural research and development, adoption of Good Agricultural Practices (GAP), conservation agriculture technology, implementation of farmers friendly policies, judicious use of available resources and inputs, along with improved market and transportation facility, minimum support price (MSP) reform, supported by adequate and timely availability of bank credits. It has been reported that a rise in MSP will raise farmer income by 13-26 per cent. Smart farming and credit supporting smart farming are other possible strategies in doubling farmer's income. When we talk about diversification, it mostly deals with high value crops. Economic and socioecological access to sustainable production could be only ensured by adopting farming system approach. 


\section{Introduction}

Agriculture is the mainstay of economy in Bihar and contributing nearly 24.84 per cent to the State Gross Domestic Product (201112) and about 19 per cent to State Net Domestic Product. It provides employment to about 67 per cent of the rural population. Fertile Gangetic alluvial soils, abundant water resources and congenial weather conditions build a firm base for agriculture in Bihar. Agricultural growth rate (about 5.6 per cent) has been extremely volatile due to recurring natural disasters and productivity of crops remains low as compare to the national average. Farming households constitute about 51 per cent of rural households in the state. Marginal farms constitute 91 per cent of the farm households and own 57 per cent of the operational landholdings. The fragmented landholdings and low productivity of human labour continues to be the characteristic feature of rural Bihar. The continued involvement of rural population in farming alone requires a steady flow of income from agriculture and allied activities. Though, agriculture supports more than two third of Bihar's population, per annum household income of farmers of the state is only Rs. $3,558 /-$, which is 45 per cent lower than the household income at the national level for the agricultural year July 2012 to June 2013 (NSSO, 2014).

Doubling farmer's real income by 2022 is a goal established by the Honourable Prime Minister of India who is challenging the status of all involved stakeholders. Production and productivity increase in agriculture alone will not ensure doubling farmers' income (Srinivasan, 2017). To overcome obstacles and establish a direction for rural poverty in India, the members of NITI Aayog, ICAR and Scientists jointly hosted a meeting to brainstorm the idea of doubling farmers' income. Delegates from the Department of
Agriculture, GOI, national research institutions, central/state agricultural universities, the private sector, international research centers, and NGOs were also convened to develop a strategy for meeting the PM's challenge (Wani and Singh 2017). However, experts are engaged in searching the options and strategies for achieving this enviable target. One of the options is to evaluate the potential of the IFS approaches to enhancing the income of farm families within a reasonable time period. Mixed farming based enterprise combinations for their contribution to sustainable production as well as the livelihood of farm families with income enhancement as a major plank.

The will of the present Government to double the incomes of farmers by 2022 as announced by the Honourable Finance Minister during his Budget Speech on February 29, 2016, has been greeted with less of optimism and more of scepticism by economists and other columnists (Anonymous, 2016). Later the Honourable Prime Minister of India gave a call to the nation of doubling farmers' incomes by 2022 by spelling out six points strategy. The budget for the year 2017-18 allocated Rs. 1,87,223/- crores for agriculture and rural development, which is 24 per cent higher than last year (Anonymous. 2017a). The doubling farmers' income would involve massive investments in agricultural research and development, irrigation, fertilizers, agricultural market infrastructure including development of Agricultural Produce Market Committee (APMC) and agriculture value chains, supported by adequate and timely availability of bank credit, implementation of a number of schemes for revival of agricultural growth and farmers' welfare (Jadhav, 2017). Dignitaries and top experts from the government, industry, research, and academic bodies, farmers organisations, parliamentarians and NGOs added their relevant suggestions in the National Round 
Table on 'Doubling Farmers' Income by 2022" held in New Delhi chaired by Prof. M.S Swaminathan and co-chaired by the Secretary (Ministry of Agriculture), Government of India. This National Round Table given a total of 40 recommendations for increasing incomes of farmers have been divided into five major parts which among these IFS approaches will play a most important role (Khan 2016). 1.) Increasing incomes by improving productivity, 2.) Water and agri-input policies, 3.) Integrated farming system, 4.) Better market price realization and 5.) Special policy measures.

Farming in India is characterized by small and fragmented land holdings which rely on monsoon rains. Operating small holdings is often unviable and under this situation farming is not a profitable business or enterprise (NCAER 2017). Farmers earn income from various sources, viz. crop cultivation, horticulture, dairy, poultry, fisheries, other allied activities, non-farm activities, and wage employment. The income disparity between farmers and non-farmers has increased during the last three decades. In 1983-84 the average income of a farm household was about a third of that of a nonfarm household which had reduced to onefourth by the year 2004-05. There was some improvement during the subsequent period, up to 2013-14, due to agriculture growth (Kumar et al., 2012).

For doubling of the farmer's income some strong strategies need to be adopted considering the basic requirement of the farmers. These strategies might be massive investments in agricultural research and development, adaption of GAP, conservation agriculture technology, implementation of farmers friendly policies, judicious use of available resources and inputs, along with improved market and transportation facility, MSP reform, supported by adequate and timely availability of bank credits. It has been reported that a rise in the MSP will raise farmer income by 13-26 per cent (Sodhi, 2017). India is also the world's largest and fastest growing market for milk and milk products. On average, livestock contributes about 12 per cent of farmers' income in India (Chand 2017). Smart farming and credit supporting smart farming are one of another possible strategy for doubling farmers' income. Diversification can prove as a game changer, involving high value crops.

\section{Why farming system approach?}

In system approach all the components and activities are linked, they affect each other. In agriculture, management practices were usually formulated for individual corp. However, farmers are cultivating different crops in different seasons based on their adaptability to a particular season, domestic needs and profitability.

- It enables to identify the major constraints in increasing farm productivity.

- To understand the physical and socioeconomic environment within which agricultural production takes place.

- To gain an understanding of the farmer in terms of his/her skills, constraints, preferences and aspirations.

- To comprehend and evaluate the performance of existing important farming systems.

IFS Approaches is holistic, multidisciplinary, dynamic, problem solving, location specific and farmer needs oriented, which make a vital contribution to sustainable development by adding consideration of economic, ecological and social objectives to the essential business of agricultural food production. The wellbeing of farmers can be improved by bringing together the experiences and efforts of farmers, scientists, researchers, and students 
at different locations with similar ecosociological system. In addition to this, proactive government policies and institutional support are the needs of the hour to make IFS approach successful for small and marginal farmers of developing countries like India (Kumar 2013).

Conservation agriculture (CA) technology can also play a vital role in the reduction of labour requirement for nursery preparation, tillage, and replanting. There was a difference in perception among men and women farmers with respect to yield enhancement by the adoption of CA technologies. The male and female group cited the almost similar problem of zero tillage technology adaption. Key problems and issues affecting the performance CA technologies in Bihar include poor germination, weeds and limited skills of machine operators. Weed control was the primary problem faced by the farmers due to the zero-tillage approach and the problem was more expressed due to the nonavailability and high cost of suitable herbicides on time. The limited skills of agricultural machine operators and uneven plots also contributed to the uneven sowing of the seed through ZT machine and seedlings through paddy transplanter (Kumar et al., 2017).

Major challenges and issues under agriculture in Bihar

- Occurrence of natural calamities (frequent floods, drought and hail storm etc.).

- Low productivity in Tal and Diara land area.

- High cost \& less availability of hybrid seeds/HYV.

- Low spread of hybrid and high yielding varieties.

- Less use of rice fallow land.
- Delay sowing of crops.

- Imbalance or excessive use of chemical fertilisers and pesticides.

- High cost of production.

- Low level of farm mechanization.

- Market price fluctuation in on and off season.

- Lack of marketing and transport infrastructure, primary processing facility.

- Low productivity of major crops comparison to national level.

- Few and low potential of storage and processing facilities.

\section{Farming system and its components}

Farming system is a complex inter-related matrix of soil, plants, animals implements, power, labour, capital and other inputs controlled in part by farm families and influenced by varying degrees of political, economic, institutional and social forces that operate at several levels. It is a resource management strategy to achieve economic and sustained production to meet diverse requirement of farm household while preserving resource base and maintaining a high level of environmental quality. It represents integration of farm enterprises such as cropping systems, animal husbandry, fisheries, forestry, sericulture, poultry etc. for optimal utilization of resources bringing prosperity to the farmer.

The main objective of the farming system is sustainability where, production process is optimized through efficient utilization of inputs without infringing on the quality of environment with which it interacts on one hand and attempt to meet the national goals on the other (Suhas and Singh, 2017). Farming systems concept is a combination of one or more enterprises with cropping especially for small and marginal farmers. 


\section{Crop production}

In farming system, there is a need to encourage adoption of integrated farm practices, methods and technologies which can increase productivity and income in different ways which are cost effective and ecologically protective. The cultivation of cereals, vegetables, fruits with other enterprises should be integrated in such a way that various parts can be complimentary and supportive to each other. Irrigation is an extremely important input for higher and sustainable agricultural production in the state along with quality seeds of High Yielding Varieties (Malhotra, 2017).

\section{Animal husbandry / livestock}

Animal husbandry has a major role in doubling farmers' income. It is now unanimously accepted by farmers that integrating animal husbandry activities with agriculture can double the income. Animal husbandry is an important integral component of Indian agriculture supporting livelihood of the rural population. Livestock farming can increase their income by adopting the new methodology, good animal husbandry practices, modern and innovative farming techniques in animal husbandry practices as well as IFS in animal husbandry practices (Prabhakar and Bharti, 2018).

\section{Fisheries}

Abundant aquatic reservoirs of Bihar have low fish productivity. Fisheries are contributing 1.5 per cent of the total GDP of the state. In 2015-16, the production of fish in Bihar was about 5.07 lakh tonnes with an annual growth rate of 10 per cent (Government of Bihar, Finance Department, Economic Survey, 2016-17). Some strategies are adopted for fisheries development such as establishment of fish hatchery in aquaculture and use of seasonal and perennial pond for stocking and throughout availability of good quality fingerlings and yearlings, to start the integrated fish farming cum refine aquaculture technology etc.

The state government has supported installation of fish feed mill and construction of fish seed hatching on subsidies rate. To facilitate fish marketing, the scheme of distribution of moped-cum-icebox has been introduced. Two or three- wheeled vehicles have also been introduced on subsidies rates for fast movement of fish to the market.

\section{Sericulture}

Sericulture is an agro-industry of rural communities, the end product of which is silk. Sericulture involves three activities viz., cultivation of mulberry, rearing, of silkworm from the cocoons formed by the worms. The second largest producer of mulberry silk is India after china (Anonymous. 2017b). Currently, 2.82 lakh ha area of mulberry plantation produces about 1.27 lakh tons of reeling cocoons and 0.14 lakh tons of raw silk. Sericulture is practiced both in tropical and temperate climates. India exports silk mainly to USA, Germany, United Kingdom, France, Italy, Singapore, Canada, UAE, Switzerland, Netherlands, Spain, Japan, Thailand etc. (Anonymous, 2013).

\section{Agro-forestry}

Agriculture and forest are always vulnerable to unfavourable climatic condition. Natural calamities, such as floods, drought, water logging etc. occur almost every year, combined with the effects of deforestation, forest degradation and errosion in Bihar. Agroforestry is an integrated self-sustained land management system, which involves deliberate introduction of materials like timber, pulp, pole, fuel wood, food and medicine with agricultural crops on the same 
unit of land, meeting the ecological and socioeconomic needs of farmers. This system also provides to varied needs of the farmer enhance employment opportunities by spreading labour needs which otherwise are concentrated in the farming system (Anonymous. 2013). The perennial characteristic of trees helps to make the best use of crop land through plantation on corner bounderies with well managed.

\section{Apiculture (Beekeeping)}

Bihar is enriched with highly diversified, abundant bee-flora and favourable ecological condition. The honey production potential is about three times $(60-65 \mathrm{~kg})$ higher than the national average $(20 \mathrm{~kg})$ and very high than any state of India, viz., Punjab $(30 \mathrm{~kg})$, H.P (35 kg) and Haryana (20 kg) per hive per year (Dalwai 2017). The litchi honey produced in Bihar has better taste, colour and flavour than the honey produced in other states due to variation in ecological condition. Litchi honey is very popular and has high demand nationaly and internationally. Honey bees act as excellent pollinators and therefore improve the yield of various agricultural crops. In Bihar, migratory beekeeping was developed by AICRP (Honeybee), Pusa centre since 1993 which have been proved beneficial for producing different types of honey in different areas, which resulted in considerable increase in yield and colony existence. By adopting of migratory beekeeping, beekeepers may harvest different honey flows as well as their income.

\section{Mushroom production}

Nutritional level of poor farmers can be improved by increasing mushroom production. There is considerable demand of medicinal mushrooms in addition to edible mushroom species. Straw is being better utilized by promoting mushroom production.
For this, the availability of mushroom seeds and quality compost is important. So far, 7 mushroom span units have been established in the state to overcome the shortage of its seeds. The production is being encouraged by setting up a group of mushroom producing farmers, especially the women farmers. The production is being linked to market. The government has also targeted to setup 20 mushroom production units and 10 mushroom span units by 2022 .

\section{Makhana cultivation}

Makhana is also a high potential commercial crop in Bihar. In India the total production of makhana is about 50,000 tons out of which the state of Bihar contributes about 80 per cent of the production. The makhana market is of about 400-500 crores in the state which has a high export potential and can be exported to Middle East countries. Beside of this, there are vast investment opportunities in Bihar for establishment of makhana processing unit (e.g. unit for producing makhana pops, making flavoured and/or roasted makhana snacks, RTC kheer, baby food, etc.).

\section{Fruit and vegetable $(F \& V)$ production and processing}

Bihar ranks first among all the Indian states in terms of vegetable production. The total vegetable production in the state was about 145 lakh tonnes in 2014-15. Likewise, major fruits production includes banana (15.27), mango (12.72), guava (3.7) and litchi (1.98 lakh tonnes). However, large quantity of fruits and vegetables are lost due to lack of processing and sufficient cold storage facilities. There are enormous investment opportunities in Bihar for establishment of allkindsof $\mathrm{F} \& \mathrm{~V}$ processing units (including units for manufacturing dehydrated and frozen $\mathrm{F} \& \mathrm{~V}$ items using IQF/Blast 
freezer/Spiral Freezer, etc.). The efficient fruit and vegetable value chain needs to be replaced with a modern ecosystem with welloriented backward and forward linkages (Anonymous, 2018). Therefore, it is necessary to set up on farm primary processing centres for the horticulture and vegetable produce to minimize the postharvest losses.

\section{Paddy cum fish culture}

The system of farming is most prevalent in Japan, China, Indonesia, India, Thailand and the Philippines. Many researchers suggest that integrated rice-fish farming is ecologically eco-friendly sound because fish enhance the fertility of soil by increasing the availability of nutrients such as nitrogen and phosphorus (Giap et al., 2005; Dugan et al., 2006). In it, the fish species selected for cultivation should have a faster growth rate. Species such as Labeorohita, Catlacatla, Anabas testudineus, Oreochromis mossambicus, Clariasbatrachus, Clarias macrocephalus, Channastriatus, Channa punctatus, Channamarulius, Chanoschanos sp. etc have been most commonly cultured in rice field.

Integrated rice-fish farming is also an important component of integrated pest management in rice crops (Berg, 2001; Halwart and Gupta, 2004). Fish play a significant role in controlling aquatic weeds and algae that carry diseases, act as host for pests and struggle with rice for nutrients. Moreover, fish eat flies, snails, and insects, and can help to control mosquitoes causing malaria and water-borne diseases (Matteson, 2000). The bio-control of rice pests is one of the prominent features of rice-fish farming which further minimize the use of pesticides for production of rice crop i.e. minimizes the cost of production because insects and pests are consumed by the fish.

\section{Role of Farming System approaches Food security}

Food security refers to the availability of food and one's access to it. A household is considered food-secure when its occupants do not live in hunger or fear of starvation. Economic and ecological access to food could be only ensured by adopting farming system approach. Integrated use and management of land, water and human resources prove to maximize income and employment.

\section{Provides balanced food}

There is need of farming system which has several components like dairy, poultry, goatry, fisheries etc. along with crop production. In this way, farming system would not only meet the food demand but also cater the need of protein, fat, vitamins and minerals required for good health. Incorporation of horticulture and agroforestry with cropping would ensure seasonal access to fruits, fuel, fodder and fibre.

\section{Quality food basket}

As the living status is improved, the requirement of cereals will be decreased and supplemented by other items viz. milk, egg, meat, fruit etc. Integration of allied enterprises with cropping increases the nutritive value of the products.

\section{Higher productivity and enhanced farm income}

Integration of fish in rice system decreased rice grain yield due to the presence of fish trenches occupying $10 \%$ of the rice area; however, additional income increases. The profit can be increased more when fish, vegetables and livestock are included in ricerice farming system. 


\section{Effective recycling of resources}

The effective recycling of farm resources is possible by adoption of farming system research. Crop by-product is utilized as fodder for animals, and animal by-product i.e. milk, and dung may be utilized for increasing income and soil fertility, respectively.

\section{Minimize environmental pollution}

In Punjab, Haryana, western Utter Pradesh and Bihar burning of rice residue is common practice, which increased the concentration of green house gases in atmosphere, in addition to huge amount of nutrient loss. Such situation could be avoided by introduction of some more enterprises like animal husbandry on the farm. Rice straw may be used as animal feed.

\section{Employment generation}

Since crop based agriculture is highly season specific and time bond, the intensity of labour requirement increases during sowing and harvesting time of crops. For rest of the time, farmers sit idle if they do not have off-farm activities. This leisure time could be utilized effectively by adoption of farming system, which keeps the whole family busy throughout the year.

Strategies for doubling the income of farmers in Bihar

\section{By increasing productivity of crops}

i.) Timely supply of good quality seeds prior to season

ii.) Adapting Good Agricultural Practices

iii.) Timely availability of good quality inputs

iv.) Providing short duration and high yielding varieties

v.) Promoting farm mechanization

vi.) Adaption of integrated nutrient management

vii.) Use of integrated pest management

vii.) Increasing irrigation facilities

\section{By increasing cropping intensity}

According to land situation, irrigation and other facilities farm plan should be prepared for Kharif, Rabi and Zaid for 03 years e.g.

$$
\begin{aligned}
& \text { Paddy - wheat/pulses/Maize } \\
& \text { Maize - Wheat/Pulses/Maize } \\
& \text { Maize - Wheat/Pulses/Maize - Mung } \\
& \text { Vegetable (cauliflower) - potato - onion - } \\
& \text { mung } \\
& \text { Maize/Vegetable - Potato-Onion - Mung } \\
& \text { Paddy (short duration) - vegetable - onion } \\
& \text { - maize } \\
& \text { Paddy - vegetable - maize etc. }
\end{aligned}
$$

\section{Diversification of farming system with high value crops}

Crop diversification includes lot of promises in alleviating the problem of low productivity, sustainability, soil health, low income, etc. through fulfilling the basic needs and regulating farm income, with standing weather aberrations, controlling price fluctuation, ensuring balance food supply, conserving natural resources, reducing the chemical fertilizer and pesticide loads, environmental safety and creating employment opportunity. Strategic diversification of crops and enterprises is needed to provide higher inclusive development in Bihar. Evidence on diversification have shown that the ratio of gross returns to cereals in high value crops in the state was 2.07 in fruits, 1.08 in vegetables and 1.55 in flowers (Saxena et al., 2017). In order to mitigate the adverse effect of climate change on agricultural crops, improve soil health and to increase the farmer's income, following crop diversification models need to be promoted. 
i.) Cash crops: Sugarcane, Betel leaf and Vegetables etc.

ii.) Spices: Turmeric, Ginger, Dhania, Garlic, Ajwain and Saunf etc.

iii.) Medicinal and Aromatic Plant: The returns from medicinal plants like safedimusali, sarpgandha, satawari, are fairly high. Similarly, returns from aromatic plants like lemon grass, rosa species, etc. are yield better returns and also their cost of cultivations are lower in comparison to many of the field crops (Singh 2013).

Medicinal Plants Suitable for Bihar:Sadabahar (Catharanthus roseus), Sarpgandha (Rauvolfia serpentine), Kalmegh (Andrographis paniculata), Brahmi (Centella asiatica), Buch (Acorus calamus), Pippli (Piper longum), Shatawari (Asparagus racemosum) etc.

Aromatic Plants Suitable for Bihar:- Lemon grass (Cymbopogon fleuosus), Palma rosa (Cymbopogon martinii), Java citronella (Cymbopogon winterianus), Mentha (Mentha arvensis), Tulsi (Ocimum basilicum), Vetiver (Vetiveria zizanioides) etc.

iv.) Flowers: Inclusion of floriculture/ flowers in peri-urban area of Bihar is one of the biggest opportunities to create income throughout the years for farmers.

v.) Mushroom cultivation: Nutrition levels of poor farmers can be improved by increasing mushroom production.

There is considerable demand for medicinal mushroom in addition to edible mushroom species.

The production is being encouraged by setting up a group of mushroom producing farmers, especially the women farmers.

vi.) Diversification of rice: wheat system with inclusion of vegetables for higher income in peri-urban areas, as well as in drought porne upland areas where rice productivity is very low due to insufficient of rainfall (e.g. Jamui, Banka, Nawada districts etc.).

\section{By reducing cost of production}

- Provision of subsidy on farm inputs, mechanization cost and diesel

- Provision of subsidy on HYV/ hybrid seeds

- Application of balance dose of fertilizer on the basis of soil testing

- Use of green manuring e.g. Dhaincha, Moong, Cowpea, Sunhemp etc.

- Use of bio fertilizers:-e.g. Rhizobium, PSB, Azotobactor, Azolla, Blue green Algae, Mycorrhiza etc.

- Subsidy on transport

- Use of renewable energy sources i.e. Solar energy, Gobar/Bio gas etc.

- Promotion of DSR/Zero tillage technology

- Promotion of custom hiring system

- Promotion of integrated farming system: Synergise blending of crops/horticulture, dairy, fishery, and poultry to provide regular income.

Protected cultivation of vegetables and flowers with micro irrigation

Protected cultivation of high value vegetables and flowers with micro irrigation has great potential to double or more the farmer's income. These technologies are very useful for small landholder growers which help to maximize their productivity levels to boost up economic relevance and sustain social stability.

\section{Use of rice fallow land}


Inclusion of pulses like lentil and lathyrus, and other oilseeds crops like linseed and safflower in rice- fallow land area of agroclimatic zone IIIA and IIIB of Bihar.

\section{Policy implementation and MSP reform}

Policy implementation can directly influence farmer's income and provide opportunities and harness potential of technologies. NITI aayog and ministry of agriculture, GOI are working together to persuade states to adopt and implement reforms that can bring changes in the existing agricultural scenario. Price incentive for producer, promoting agricultural investments, promoting modern supply or value chains, promotion of producer alliances, linking of producers and processors and not the less coordination and involvement of ministries of centre and states all together can mark a difference in doubling the farmers' income (Dwivedi et al., 2017). National Agriculture Market (eNAM) is a digital-India electronic trading portal which networks the existing Agricultural Produce Marketing Committee (APMC) mandis to create a unified national market for agricultural commodities. The eNAM portal provides a single window service for all State Agricultural Marketing Board/APMC related information and services. It includes the arrivals and prices, buy and sell trade offers, provision to respond to trade offers, among other services of commodities. While material flow (agriculture produces) continue to happen through mandis, an online market reduces transaction costs and information irregularity (Anonymous, 2017).

In conclusion, the low and highly fluctuating agricultural productivity and farm income are major sources of agrarian distress. However, agricultural growth in Bihar has been extremely volatile due to frequent natural disasters like floods in north Bihar and droughts in south Bihar. The productivity of major crops has been increased with augmenting inputs such as irrigation, fertilizers, quality seeds and farm mechanisation. Doubling real income of farmers still 2022 or over, required annual agricultural growth rate of more than 10 per cent against the present growth rate of about 2.1 per cent. This implies that the current and previously achieved growth rate has to be sharply accelerated. Concluded that adoption of farming system approaches combined with allied innovative approaches plays an important vital role to meet the present day's challenges in agriculture. It needs to transformation to provide divers set of services that support diversification with high value crops, agricultural livelihoods and offering relevant technologies that are integrated with appropriate credit support smart farming as well as policies implementation with MSP reform. IFS is also an eco-friendly approaches for doubling farmers' income in which waste materials of one enterprise becomes the input of another thus, it makes efficient and sustainable use of farm resources.

\section{References}

Anonymous (2013). Farming Systems for Sustainable Agriculture. Sustainable Livelihood in Agriculture. National Institute of Agricultural Extension Management, Rajendranagar, Hyderabad - 500 030, Andhra Pradesh, India pp 7-24.

Anonymous (2016). Doubling the Income of Farmers. Press Information Bureau. Ministry of Agriculture \& Farmers Welfare, Government of India. Finance Minister Budget Speech, February 22, 2016.

Anonymous (2017a). India Budget Statement 2017. Press Information Bureau. Ministry of Agriculture \& Farmers Welfare, Government of India.

Anonymous (2017b). Department of Economics, University of Jammu, 2017. 
National Conference on "Roadmap for Doubling Farmers' Income by 2022: Towards Addressing Agriculture Sustainability and Ways Forward. 29-30 March, Jammu.

Anonymous (2018). Value chain development, Market linkages and trade Potential. Doubling of Farmers' Income by 2022, Strategy Document for Bihar. ICAR, Department of Agricultural Research and Education, Ministry of Agriculture \& Farmers' Welfare, New delhi. pp 105-119.

Berg, H. (2001). Pesticide use in rice and ricefish farms in the Mekong Delta, Vietnam. Crop Protection 20: 897-905.

Chand, R. (2017). NITI Aayog. GOI. Doubling of Farmers' Income. Rational, Strategy, Prospects and Action Plan. National Institute of Transforming India. Kurukshetra, A journal of rural development 65(4\&8): 1-60.

Dalwai, A. (2017). Doubling of Farmers' Income: Agricultural growth and farmers welfare. Kurukshetra, A journal of rural development 65(8): 5-14.

Dugan, P., Dey, M.M. and Sugunan, V.V. (2006). Fisheries and water productivity in tropical river basins: enhancing food security and livelihoods by managing water for fish. Agricultural Water Management 80: 262-275.

Dwivedi, S., Lata, K., Sharma, P.K. and Singh, H. (2017). Doubling Farmers' Income by 2022: A Critical Appraisal. Agro Economist - An International Journal Citation: AE 4(1):29-34.

Giap, D.H., Yi, Y. and Lin, C.K. (2005). Effects of different fertilization and feeding regimes on the production of integrated farming of rice and prawn Macrobrachium rosenbergii (De Man). Aquaculture Research 36: 292-299.

Halwart, M. and Gupta, M.V. (2004). Culture of fish in rice fields. Food and Agriculture Organization of the United
Nations and the World Fish Center. pp 83.

Jadhav, A. (2017). Synoptic note - doubling of farmers income by 2022; scope and strategies. Agri Business Management Student at Indian Institute of Plantation, March 1, 2017.

Khan, M.J. (2016). Indian Council of Food and Agriculture. India International Centre, 30 April, New Delhi.

Kumar, S., Dey, A., Kumar. U., Chandra, N. and Bhatt, B.P. (2012). Integrated Farming System for Improving Agricultural Productivity. Status of Agricultural Development in Eastern India 205-230.

Kumar, S. (2013). Integrated Farming System models for food and nutritional security. Lecture Delivered During Model Training Course on Gender Perspective in Integrated Farming system w.e.f January 17-24, 2013 at ICAR Research Complex for Eastern Region, Patna, Bihar

Kumar, U., Bharati, R.C., Chaubey, R.K., Rao, K.K., Prakash, V. and Kumar, A. (2017). Farmers Perception in Adoption of Conservation Agriculture practices in Madhubani District of Bihar, India. Journal of AgriSearch 4(4): 285-289

Malhotra, S.K. (2017). Initiatives and Option in Transition for Doubling Farmers Income. Shodh Granth. National Conference on Technological Changes and Innovations in Agriculture for Enhancing Farmers' Income organized by JAU, Junagadh, Gujarat. pp 1-13. May 28-30, 2017.

Matteson, P.C. (2000). Insect-pest management in tropical Asian irrigated rice fields. Annual Review of Entomology 5: 549-574.

NCAER. (2017). Doubling of Farmers' Income in India: Backdrop and Challenges. National Council of Applied Economic Research. pp 1-25. 
March 7, 2017. New Delhi.

NSSO. (2014). National Sample Survey Office. Ministry of Statistics and Programme Implementation. GOI. http://www.mospi.gov.in/

Prabhakar, P. and Bharti, M.K. (2018). Role of veterinary doctors in doubling farmer's income. Animal Husbandry. https://krishijagran.com/animalhusbandry/role-of-veterinary-doctorsin-doubling-farmer-s-income/

Satyasai, K.J.S. and Bharti, S. (2016). Doubling Farmers' Income: Way Forward. Rural Pulse. XIV pp 1-4.

Saxena, R., Naveen. P.S., Balaji, S.J., Usha, R.A. and Joshi, D. (2017). Strategy for Doubling Income of Farmers in India. Plicy paper 31. National Institute of Agricultural Economics and Policy Research (NIAP), New Delhi.

Singh, K.M., Kumar, A., Singh, R.K.P. and Kumar, U. (2013). Medicinal and Aromatic Plants for Enhancing Farm Income: The Case of Bihar. Munich Personal RePEc Archive. ICAR-RCER, Patna. pp 1-17.

Sodhi, R.S. (2017). Managing Director, Gujarat Cooperative. Milk Marketing Federation Ltd.
Srinivasan, K. (2017). Sustainable Development of Farm Holders through Integrated Farming and Mechanization. National Bureau of Soil Survey and Land Use Planning (NBSS-LUP), Nagpur KISAN-MITrA. No: 3 pp 1824. 15-16 March 2017. New Delhi.

Suhas, P.W. and Singh, D. (2017). Doubling Farmers' Income: Challenges and Opportunities. Proceedings of National Workshop on Doubling Farmers' Income through Scaling-up: KISANMITrA (Knowledge-based Integrated Sustainable Agriculture Network Mission India for Transforming Agriculture). No: 3 pp 2-3. March 1516, 2017. New Delhi.

Wani, S. P., Jakkula, V. S. and Singh, D. (2017). Doubling Farmers' Income: KISAN-MITrA, Proceedings of National Workshop on Doubling Farmers' Income through Scalingup: KISAN-MITrA (Knowledge-based Integrated Sustainable Agriculture Network - Mission India for Transforming Agriculture). Monograph. ICRISAT, Patancheru, Hyderabad.

\section{How to cite this article:}

Dayanidhi Chaubey, Ved Prakash, Tikam Chand Yadav and Garima Singh. 2018. Doubling of Farmers' Income though Integrated Farming System Approaches in Bihar- A Review. Int.J.Curr.Microbiol.App.Sci. 7(12): 1602-1613. doi: https://doi.org/10.20546/ijcmas.2018.712.188 